\title{
Abortion among women living and not living with HIV \AIDS, users of the public health services in the city of São Paulo: prevalence, contexts and reasons
}

\section{Mr editor,}

The study ${ }^{1}$ addresses the association of two themes that impact the Brazilian society. The first one, an age-old taboo: induced and clandestine abortions. The second, a disease that has stigmatized people for over 30 years: AIDS. The study analyzes the prevalence of induced abortion among women living or not living with HIV. Thus, it investigates the reasons that lead pregnant women to interrupt their pregnancy and seek to find out whether HIV infection influences induced abortion.

In this sense, the study reports that the occurrence of abortions by WLHIV (Women living with HIV) was four times higher than in WNLHIV (Women not living with HIV). Therefore, it was also possible to visualize that HIV infection was reported as an important factor in the decision to interupt their pregnancy in $47.6 \%$ of the WLHIV. However, $37.4 \%$ of these women reported that the infection had little or no importance in making the decision. In addition, it highlights that both WLHIV and WNLHIV, not cohabiting with the partner, socioeconomic conditions and the lack of family support were the major influencers to undergo an abortion. ${ }^{1}$ So, it is evident that interrupting a pregnancy goes beyond living or not with HIV, making it a serious public health problem.

In the study on post-diagnosis of HIV abortion in pregnant women in the South of Brazil, the results indicate that more than half of the pregnant women stated that having HIV influenced them to undergo an abortion. In addition, but in smaller proportions, there were other motives which led to undergoing an abortion: lack of financial conditions, pregnant women or partner did not want children at that time or because they are not married.2 Therefore, it is possible to infer that the parameters of the city of São Paulo meet the same parameters as the South. According to the Brazilian Penal Code, articles 124 to 128 , clandestine abortion is considered a crime in this Country. ${ }^{3}$ In this context, the restrictive and punitive conditions of the Brazilian law when interrupting a pregnancy can be important justifications for the occurrence of clandestine abortions. Consequently, many women with obstetric complications, generated by induced abortion, limit themselves to have access to the health services.

Although, many pregnant women who undergo an abortion may have fatal complications. According to a study on complicated abortions and care at a public maternity integrated to the National Program Rede Cegonha, observed that among the causes of hospitalized pregnant women who underwent abortions were $61.5 \%$ with hemorrhage. The other $31.6 \%$ hospitalizations corresponded to other causes, but $4.3 \%$ of the cases were related to infections. ${ }^{4}$ Thus, it is possible to analyze that WLHIV, when undergoing a clandestine abortion, are more likely to have complications than a healthy person, although this is an immunocompromised patient. In addition, not only does it bring risks to HIV-positive pregnant women, but does as well as to the individual who performs the procedure of the abortion, as many patients can have hemorrhage, there are chances of HIV contamination.

In this context, it concludes that the prevalence of induced abortion in WLHIV is higher than in 
WNLHIV. In addition, it appears that the reasons for pregnant women in the South region and the city of São Paulo converge. It is understood that the complications of clandestine abortion can be serious, even more so with WLHIV, and the risks are not limited to only pregnant women. So, it is important to alert the population that induced and clandestine abortions can bring much harm and we should support pregnant women who undergo thiskind of procedure, aiming to recover them from their complications.

\author{
Maria Clara Silvestri 1 \\ iD https://orcid.org/0000-0002-2375-3182 \\ João Pedro Espíndola Gomes 2 \\ (iD) https://orcid.org/0000-0002-2596-9892 \\ Elonir Gomes 3 \\ (iD) https://orcid.org/0000-0002-0375-1374 \\ Eliane Mazzuco 4 \\ (iD) https://orcid.org/0000-0001-6496-2602
}

1-4 Universidade do Sul de Santa Catarina. Campus Tubarão. Av. José Acácio Moreira Tubarão, 121. Tubarão, SC, Brasil. CEP: 88.704-900. E-mail: mariaclarasilvestric@gmail.com

\title{
References
}

1. Pinho AA, Villela WV, Barbosa RM. Aborto entre mulheres vivendo e não vivendo com HIV \AIDS usuárias de serviços públicos de saúde no município de São Paulo: prevalência, contextos e motivo. Rev Bras Saúde Mater Infant. 2019; 19 (4): $851-63$.

2. Pilecco FB, Teixeira LB, Vigo A, Knauth DR. Aborto pósdiagnóstico em mulheres vivendo com HIV/Aids no sul do Brasil. Ciênc Saúde Coletiva. 2015; 20 (5): 1521-30.

3. BRASIL. Decreto de Lei ${ }^{\circ} 2.848$, de 07 de dezembro de 1940. [acesso 18 Abr 2020]. Disponível em: http://www.planalto.gov.br/ccivil_03/decretolei/del2848compilado.htm
4. Adesse L, Silva KS, Bonan C, Fonseca VM. Complicações do abortamento e assistência em maternidade pública integrada ao Programa Nacional Rede Cegonha de saúde nos serviços de atenção à saúde: a experiência em Santa Catarina, Brasil. Saúde Debate. 2015; 39 (106): 694-706.

Received on April 26, 2020

Approved on May 4, 2020 